\title{
USE OF PERFLUOROCARBON BASED BLOOD SUBSTITUTE PERFTORAN IN CORRECTION OF HYPOXIA DURING ACUTE ANEMIA IN ANIMALS
}

Sergey Vladimirovich Votrin ${ }^{1}$, Sergey Ivanovich Vorobyev ${ }^{1}$, Sergey Bolevich ${ }^{1}$, Stefani Sergeyevna Bolevich ${ }^{1}$, Aleksandra Orlova ${ }^{1}$, Bella Isayevna Tachieva $^{1}$, Korsakov Dmitriy Yriyevich ${ }^{1}$, Nguyen Minh Tuan ${ }^{1}$, Tatyana Georgiyevna Sinelnikova ${ }^{1}$, Aleksandar Novikov ${ }^{2}$ and

Israpil Alisultanovich Omarov ${ }^{3}$

${ }^{1}$ I.M. Sechenov First Moscow State Medical University (Sechenov University), Moscow, Russia

${ }^{2}$ The Federal state budgetary institution "The Federal bureau for medical-social expertise" of Ministry of labour and social protection of the Russian Federation (FSBI FB MSE of Mintrud of Russia); Moscow, Russia ${ }^{3}$ RUDN University, Moscow, Russia

\section{UPOTREBA ZEMENE ZA IRV ZASNOVANE NA PERFLUOROKARBONU ZA KORIGOVANJE HIPOKSIJE TOKOM AKUTNE ANEMIJE KOD SISARA \\ Sergey Vladimirovich Votrin ${ }^{1}$, Sergey Ivanovich Vorobyev ${ }^{1}$, Sergey Bolevich ${ }^{1}$, Stefani Sergeyevna Bolevich ${ }^{1}$, Aleksandra Orlova ${ }^{1}$, Bella Isayevna Tachieva $^{1}$, Korsakov Dmitriy Yriyevich ${ }^{1}$, Nguyen Minh Tuan ${ }^{1}$, Tatyana Georgiyevna Sinelnikova ${ }^{1}$, Aleksandar Novikov ${ }^{2}$ i Israpil Alisultanovich $\mathrm{Omarov}^{3}$ \\ 'Prvi moskovski držani medicinski univerzitet I.M. Sečenov (Sečenov Univerzitet), Moskva, Rusija \\ ${ }^{2}$ Federalna državna budžetska institucija "Savezni biro za medicinsko-socijalnu ekspertizu” Ministarstva rada i socijalne zaštite Ruske Federacije (FSBI FB MSE Mintrud Rusije), Moskva, Rusija \\ ${ }^{3}$ RUDN Univerzitet, Moskva, Rusija}

Received / Primljen: 20. 06. 2018

Accepted / Prihvaćen: 25. 07. 2018.

\section{ABSTRACT}

The cause of acute and severe hypoxia of the organism is acute posthemorrhagic anemia. To eliminate posthemorrhagic anemia in animals, the perfluorocarbon blood substitute Perftoran (Russia) with a gas-transporting function was used. The aim of this study was to determine the clinical effectiveness of the perfluorocarbon based blood substitute Perftoran with a gas-carrying function in acute posthemorrhagic anemia in animals and reveal possible side effect of the blood substitute and remove them. In the study conducted in the Clinic of Veterinary Medicine of Pushchino Research Center (Russia) participated 20 cats of both sexes, who were admitted with internal bleeding as a result of injuries. The animals were divided into two groups: the control and the treatment groups (10 per group). All animals with anemia were examined according to the standard scheme: anamnesis vitae and anamnesis morbi, physical examination (basic methods of research were used), additional methods that were used: complete blood count $(C B C)$ and biochemical analysis of blood (BA), microscopy of blood smears, abdominal ultrasonography. Based on the obtained results, we can conclude that the use of the gas-carrying substitute for donor blood Perftoran in the treatment group of animals with posthemorrhagic anemia, which resulted from polytrauma, eliminated tissue hypoxia; the treatment of the animals in the control group with standard solutions (by infusing Stabisol) without gas transport correction led to the development of persistent hypoxia, which persisted to the stage of reticulocyte crisis.

Key words: perfluorocarbon blood substitute, hypoxia, cats

\section{SAŽETAK}

Uzrok akutne $i$ teške hipoksije organizma je akutna posthemoragična anemija. U cilju sprečavanja posledica posthemoragične anemije kod životinja, korišćena je zamena za krv na bazi perfluorokarbona Perftoran (Rusija) koji ima ulogu transportera gasova. Cilj ovog istraživanja je bio utvrdivanje kliničke efikasnosti zamene za krv na bazi perfluorokarbona (Perftoran) sa funkcijom nosača gasova u akutnoj posthemoragijskoj anemiji kod životinja i ispitivanju mogućih neželjenih efekata $i$ njihovog uklanjanja. U istraživanje sprovedeno na Klinici za veterinarsku medicinu istraživačkog centra Pushchino (Rusija) je uključeno 20 mačaka oba pola, koje su primljeni sa unutrašnjim krvarenjem kao posledica povreda. Životinje su podeljene u dve grupe: kontrola $i$ grupe za lečenje (10 po grupi). Sve životinje sa anemijom ispitane su u skladu sa standardnom šemom: anamnesis vitae $i$ anamnesis morbi, fizički pregled (korištene su osnovne metode istraživanja), a kao dodatne metode korišćene su: potpuna krvna slika $(C B C)$ i biohemijski analiza krvi (BA), mikroskopija krvnih mrlja, abdominalna ultrasonografija. Na osnovu dobijenih rezultata, zaključuje se da upotreba Perftorana, kao zamene za donorsku krv sa svojstvima nosača gasova, u lečenju životinja sa posthemoragijskom anemijom nastalom usled politraume, uspešno sprečava hipoksiju tkiva. Lečenje životinja standardnim rastvorima u kontrolnoj grupi sa standardnim rastvorima (rastvor Stabisol) bez poboljšanja transporta gasova uzrokovala je nastajanje uporne hipoksije, koja je perzistirala na stadijumu retikulocitne krize.

Ključne reči: zamena krvi na bazi perfluorokarbona, hipoksija, mačke

\section{sciendo} UDK:

Ser J Exp Clin Res 2019; 20 (3): 245-250 DOI: 10.2478/SJECR-2018-0056
Corresponding author: Prof. Sergey Bolevich, MD, PhD Department of Human Pathology, First Moscow State Medical, University IM Sechenov, Trubetskaya street 8, str. 2 119991, Moscow, Russia e-mail: bolevich2011@yandex.ru 


\section{INTRODUCTION}

The pathological condition of organism with a decrease in the total amount of red blood cells (RBCs) and hemoglobin in the volume of blood is called anemia. The etiological factors of anemia are diverse; they can be congenital, acquired, but regardless of the cause and pathogenesis, the common result of anemia is the decrease in the total amount of hemoglobin and RBCs in the volume of blood and as a consequence - the decrease of oxygen-carrying function of RBCs and the development of hypoxemia and hypoxia (1-4).

The most frequent cause of acute and severe hypoxia in both human and veterinary medicine is acute posthemorrhagic anemia. Acute posthemorrhagic anemia develops during the massive blood loss of $20 \%$ of the total circulating blood volume (CBV) $(2,3)$. Usually this pathological process is the consequence of injuries. There are four stages in the dynamics of acute posthemorrhagic anemia, as indicated by Alexeev et al. in his work (1).

The first is a stage of collapse and it occurs immediately after the blood loss and lasts approximately one day after the bleeding ceases. At this stage the clinical picture is dominated by the symptoms of collapse, whereas the picture of peripheral blood has almost no deviation from the norm, because with rapid massive blood loss the decrease in hemoglobin and RBCs is only due to the decrease of CBV (1-5). Compensatory factor in this stage is peripheral vascular spasm. The second is a hydremic stage in which decrease in CBV leads to the activation of mechanisms directed towards restoring the amount of fluid circulating in the vascular system: the tissue fluid passes into the vessels; the resulting thirst stimulates the flow of water into the body, which, along with a decrease in dieresis, which develops as a result of both the spasm of kidney vessels and the delay of sodium in organism under the influence of aldosterone released by adrenal glands, leads to an increase in the amount of water in vascular bed (2-7). At the same time the release of RBCs from depots to blood occurs. Hypoxia, which occurs immediately after the blood loss, activates the secretion of erythropoietin by the kidney and stimulates erythropoiesis in the bone marrow. But this process takes time, thus its first signs are observed only on the 4th5th day after the blood loss. By that time the second stage ends and the third stage begins (2-7). The final stage is a stage of reticulocyte crisis and stage of recovery in which erythropoiesis intensifies, which is indicated by the significant increase of reticulocytes, immature RBCs, in the volume of blood (9). As a result of the processes developed in the stage of reticulocyte crisis the hemoglobinization of RBCs is normalized, the color index is restored. Together with erythropoiesis, leukopoiesis is also stimulated, which is manifested in a slight leukocytosis $(3-8,10)$.

The greatest effect on the animal's organism hypoxia has is in the hydremic stage, since all RBCs reserves are consumed, and the number of RBCs may continue to decrease as a result of autoimmune hemolysis $(5,6)$. Cats' RBCs have their own features: they are more spherical and smaller in size $(40-50 \mu \mathrm{m})$ than dogs' RBCs. Their lifespan is relatively small: from 60 to 80 days. Cats have two types of hemoglobin: $\mathrm{HbA}$ and $\mathrm{HbB}$; they are present in different ratios in different individuals and have less affinity for oxygen, than hemoglobin of other animals $(7,8)$. Considering the morpho-physiological features of cats and stages of posthemorrhagic anemia, it is necessary to immediately carry out therapy aimed at eliminating hypoxia of the organism.

The best effect on elimination of systematic hypoxia can be achieved through blood transfusion, but in cats, unlike dogs, blood transfusion can lead to adverse reactions even with the first perfusion; furthermore, it is impossible to collect a clinically significant amount of blood from a donor cat (5-9).

It is known that cats have three blood groups: A, B and $\mathrm{AB}$. It is necessary to perform cross-matching, since if the donor's and recipient's blood is incompatible, the severe hemolytic reaction will occur due to the appearance of alloantibodies. The most severe reaction occurs when the $\mathrm{RBCs}$ of the blood group $\mathrm{A}$ is administered to the recipient of blood group B $(7,10)$. However, knowledge of the blood groups of the donor and recipient does not guarantee prevention of hemolytic reaction; antibodies can be present, bonded with other factors of the blood group, which have not yet been well defined in cats (9-12). Furthermore, with transfusion of incompatible blood in cats, the lifespan of donor RBCs is only several hours, therefore the therapeutic effect cannot be achieved. On the 15th day of the blood storage RBCs significantly lose elasticity of the membrane and deformability, which also reduces their therapeutic effect (13).

Well, in severe forms of anemia the use of donor RBCs in cats is limited and poses a serious threat to the recipient. Therefore, the question arises, whether the use of an artificial blood substitute, which has a gas-carrying function, for anemia in cats is advisable. The aim of this study was to determine the clinical effectiveness of the perfluorocarbon based blood substitute Perftoran with a gas-carrying function in acute posthemorrhagic anemia in animals and reveal possible side effect of the blood substitute and remove them.

\section{MATERIALS AND METHODS}

\section{Ethical approval}

All of the experimental procedures and were carried out in accordance and with the permission of the Institutional ethical committee for the welfare of laboratory animals.

\section{Protocol of study and animals}

In the studies conducted in the Clinic of Veterinary Medicine of Pushchino Research Center (Russia) partici- 
pated 20 cats of both sexes, who were admitted with internal bleeding as a result of injuries. The animals were divided into two groups: the control and the treatment groups with $n=10$ in each.

In the first, control group, traditional infusion therapy was used, which included the use of a colloidal solution Stabisol in a dose of $20 \mathrm{ml} / \mathrm{kg}$ with the oxygenation by medical oxygen with a flow saturation of $\mathrm{O} 2=87-95,5 \%$, productivity $5 \mathrm{l} / \mathrm{min}$ (oxygen concentrator Armed 7F- $5 \mathrm{~L}$ ).

According to the instruction for use, Stabisol is a volume expander (plasma-substituting agent) and a 6\% isotonic solution of synthetic colloid hydroxyethyl starch (HES) with an average molecular mass of $450000 \mathrm{Da}$. Stabisol HES $6 \%$ has a volemic effect within the $85-100 \%$ of the administered volume, which lasts for 6-8 hours, which is due to the ability of the drug to bind and retain water in the intravascular space. Stabisol HES 6\% improves the rheological properties of blood and microcirculation, as well as cerebral and feto-placental blood flow (including by reducing the hematocrit). This leads to improved blood supply to tissues, a decrease in plasma viscosity and platelet aggregation and prevents RBCs from aggregating.

In the second, treatment group, in addition to the colloidal solution of Stabisol, perfluorocarbon blood substitute Perftoran was used. Perfluorocarbon blood substitute Perftoran was developed in USSR-Russia in the period 19791996. Main works were carried out at the Institute of Biophysics of the USSR Academy of Sciences and continued at the Institute of Theoretical and Experimental Biophysics of the Russian Academy of Sciences; from 1979 to 1985 under the supervision of F.F. Beloyartsev and G.R. Ivanitsky; from 1986 to 1997 under the supervision of S.I. Vorobyev.

Synthetic blood substitute Perftoran is a $20 \%$ emulsion of perfluorinated compounds (PFCs) nanoparticles, emulsified to an average size of $100 \mathrm{~nm}$, and a gas-carrying substitute for donor blood, and, in terms of its functions, it is best suited for eliminating hypoxia in animals that has developed as a result of anemia. Most effectively the drug realizes its properties in the first 6 hours after infusion, when breathing pure oxygen or air, enriched with oxygen to $60-70 \%$. Due to the presence of chemically inert perfluorinated compounds in the drug, it is capable of dissolving $\mathrm{O} 2$ and $\mathrm{CO} 2$ up to $7 \mathrm{vol} \%$ (with $\mathrm{pO} 2=760 \mathrm{mmHg}$ ) and $60 \mathrm{vol} \%$ (with pCO2=760 mmHg), respectively. Admitted into a clinic animals with anemia were prescribed emulsion Perftoran in a dose of $10 \mathrm{ml} / \mathrm{kg}$ (this dose was recommended by the manufacturer in case of the blood loss). Infusion was carried out on animals on the 1st, 2nd, 3rd, 5th and 7th day after injury. Drug administration started with a bioassay (a gradually controlled administration): 0,1 $\mathrm{ml}$ of the drug was diluted with $0,9 \% \mathrm{NaCl}$ to $5 \mathrm{ml}$, injected slowly intravenously, and then drip with pauses of $60 \mathrm{~s}-3$, $5,10,30$ drops, gradually increasing the rate of infusion to 1 drop per sec.

In admitted sick animals viral infections were excluded: viral leukemia of cats and viral immunodeficiency using rapid tests (Vet-Expert, Poland) through chromatographic immunochemical analysis. All animals with anemia were examined according to the standard scheme: anamnesis vitae and anamnesis morbi, clinical examination (basic methods of research were used), additional methods that were used: complete blood count $(\mathrm{CBC})$ and biochemical analysis of blood (BA), microscopy of blood smears, abdominal ultrasonography.

For the $\mathrm{CBC}$, hematological analyzer (Mindray BC2800 vet, China) was used, which made it possible to monitor the gas composition of peripheral blood. The degree of anemia was determined by the hematocrit level.

For the pulse oximetry of injured animals, during the surgical intervention the device Mindray iPM 10 vet (China) was used to determine the peripheral oxygen saturation - $\mathrm{SpO} 2$.

BA of blood was performed using the biochemical blood analyzer IDEXX VetTest 8008 (USA) and Reflovet Plus (Switzerland); the lactate level was determined, which showed the degree of hypoxia at the cellular level, as well as the content of creatinine, urea, $\mathrm{K}+, \mathrm{Ca} 2+$, bilirubin, which gave information about the functional capability the of kidneys and liver.

Ultrasonography was performed immediately after the admission of the animals to clinic. To visualize the structure of the parenchymal organs, tumor changes and the presence of free fluid in the abdominal cavity, the system with the color doppler Mindray Z6 (China) was used.

\section{Statistical analyses}

Statistical data processing was carried out in the MatLab program. During the analysis, the arithmetic mean values and standard deviations were calculated. The hypothesis of equality of means in two groups was tested using one-tailed Student t-test for independent samples.

\section{RESULTS}

\section{Effects of colloidal solution Stabisol (Control group)}

By admission the clinical picture of the animals in the control group was dominated by symptoms associated with a decrease in total CBV: a sharp drop in blood pressure, paleness of skin and visible mucous membranes, tachycardia and tachypnea; hematological and clinical signs corresponded to the first stage of posthemorrhagic anemia (stage of collapse). At the same time, the hematocrit and the lactate level remained within the normal range, since the tissue hypoxia had not developed yet, and the proportional loss of plasma and blood cells did not affect the hematocrit. After the intravenous infusion of Stabisol in a dose of $20 \mathrm{ml} / \mathrm{kg}$, the animals underwent surgery to eliminate the internal bleeding. The peripheral oxygen saturation $\mathrm{SpO} 2$ in animals under general anesthesia was $89-93 \%$, and only with intensive oxygenation $\mathrm{SpO} 2$ increased to $95 \%$, which indicated acute hypoxemia. The 
animals heavily recovered from general anesthesia, the condition of three patients were critical.

Thus, in cats of the control group, posthemorrhagic anemia in the stage of collapse had a sufficiently clear clinical picture, but without the characteristic hematological changes.

On the 2nd day after the blood loss, distinct hematological signs of anemia showed in the animals: the hematocrit decreased to $19 \%$, the lactate level increased to 6 $\mathrm{mmol} / \mathrm{l}$. The clinical picture was manifested in the form of "porcelain" mucosa, shortness of breath, oppression, feed refusal and tachycardia. These hematological changes characterized the second stage of posthemorrhagic anemia (hydremic stage). The animals were given infusion of Stabisol $10 \mathrm{ml} / \mathrm{kg}$ and intensive oxygen inhalation.

On the 3rd day after the bleeding, the animals continued to be in a serious condition, distinct signs of hypoxia were evident: tachycardia, tachypnea, diaphragmatic breathing, anemic mucosa, increased thirst, loss of appetite. The animals were given another infusion of Stabisol in a dose of $10 \mathrm{ml} / \mathrm{kg}$ and intensive oxygen inhalation. The hematocrit was at the level of $20 \%$. The lactate level increased to a critical value of $6,9 \mathrm{mmol} / \mathrm{l}$. There was a lethal outcome in one animal.

On the 5th day of the animal observation, the general state stabilization was noticeable: appetite improved, the hematocrit increased to $25 \%$, which was reflected in an increase in activity, the mucous membranes became pale pink, and tachycardia disappeared. The lactate level was reduced to $5,8 \mathrm{mmol} / \mathrm{l}$, but with an increase in activity animals had shortness of breath. Clinical picture corresponded to the third stage of posthemorrhagic anemia (stage of reticulocyte crisis). The animals were given another infusion of Stabisol in a dose of $10 \mathrm{ml} / \mathrm{kg}$ and intensive oxygen inhalation.

On the 7th day of the animal observation, hematocrit of the animals in control group increased to $30,8 \%$, the level of lactate decreased to $2,7 \mathrm{mmol} / \mathrm{l}$; with increased activity, shortness of breath was absent, appetite improved, mucosa was pale pink. The animals were given another infusion of Stabisol in a dose of $10 \mathrm{ml} / \mathrm{kg}$ and intensive oxygen inhalation.

Effects of colloidal solution Stabisol in combination with perfluorocarbon blood substitute Perftoran (Treatment group)

The clinical picture of the animals in the treatment group was the same as in the control group at admission. On the 1st day, as studies showed, hematological indices in animals did not change, hematocrit 38\%, lactate level 2,6 $\mathrm{mmol} / \mathrm{l}$. Hypoxia of the tissues had not developed yet, and the proportional loss of plasma and blood cells did not affect the hematocrit. The clinical picture was dominated by symptoms associated with a decrease in total CBV: a sharp drop in blood pressure, paleness of skin and visible mucous membranes, tachycardia and tachypnea; hematological and clinical signs corresponded to the first stage of posthemorrhagic anemia (stage of collapse). To replenish
CBV Stabisol in a dose of $10 \mathrm{ml} / \mathrm{kg}$ was used according to the same scheme, as in the control group. To correct the gas composition of blood Perftoran in a dose of $10 \mathrm{ml} / \mathrm{kg}$ was used. During the infusion patients were given an oxygen inhalation. Then the animals underwent the surgery to eliminate internal bleeding.

$\mathrm{SpO} 2$ in animals under general anesthesia was $95-97 \%$, and even without intensive oxygenation $\mathrm{SpO} 2$ did not fall below $95 \%$, which indicated the absence of hypoxemia, despite the acute blood. The animals adequately recovered from general anesthesia, the patients' condition was stable.

On the 2nd day after the blood loss in animals, despite the decreasing level of the hematocrit to $16 \%$ and the distinct signs of anemia in the form of anemic mucosa, shortness of breath, oppression, feed refusal and tachycardia, the lactate level remained within the reference values. To replenish CBV and gas composition of blood patients were given another infusion of Stabisol in a dose of $10 \mathrm{ml} / \mathrm{kg}$ and Perftoran in a dose of $10 \mathrm{ml} / \mathrm{kg}$, combined with an oxygen inhalation.

On the 3rd day after the bleeding, the cats were in a satisfactory condition, the lactate level decreased to 2,5 $\mathrm{mmol} / \mathrm{l}$; despite a low level of the hematocrit of $18 \%$, the signs of hypoxia were noticeable: tachycardia, tachypnea, diaphragmatic breathing, anemic mucosa, increased thirst, loss of appetite. As a curative care patients were given infusion of Stabisol and Perftoran in the same dose, combined with an oxygen inhalation.

On the 5th day of the animal observation, the state stabilization in patients was noticeable: appetite improved, the hematocrit increased to $21 \%$, which was reflected in an increased activity, the mucous membranes became pale pink, and tachycardia disappeared. Lactate did not tend to increase and was $2,0 \mathrm{mmol} / \mathrm{l}$. To fixate a positive clinical picture, the animals were infused with Stabisol and Perftoran in the same dose, combined with an oxygen inhalation.

On the 7th day of the animal observation, the hematocrit increased to $31 \%$, whereas lactate - to $2,7 \mathrm{mmol} / \mathrm{l}$, with increased activity, shortness of breath was absent, appetite improved, mucosa was pale pink. Despite the obvious improvement of clinical and biochemical parameters, cats were given another infusion of Stabisol and Perftoran in the same dose, combined with an oxygen inhalation.

\section{DISCUSSIONS}

The aim of this study was to determine the clinical effectiveness of the perfluorocarbon based blood substitute Perftoran with a gas-carrying function in acute posthemorrhagic anemia in animals and reveal possible side effect of the blood substitute and remove them.

Prevoius studies have shown, that infusion of the gascarrying drug Perftoran, which provides an oxygen supply and helps the organism of the patient, which has received severe polytrauma, to go through the general anesthesia, surgical intervention and postoperative period, is necessary to be carried out on injured animals (14-16). 
Table 1. Dynamic of changes in hematocrit and lactate level in animals with posthemorrhagic anemia in control and treatment groups with statistical significances. * $\mathrm{p}<0.05$ represent significant differences between control and treatment groups

\begin{tabular}{|c|c|c|c|c|c|c|}
\hline \multirow{2}{*}{ Parameter } & \multirow{2}{*}{ Groups } & \multicolumn{5}{|c|}{ Time of research (days) } \\
\hline & & 1 & 2 & 3 & 5 & 7 \\
\hline \multirow{2}{*}{$\begin{array}{c}\text { Hematocrit } \\
(\%)\end{array}$} & Control & $38.00 \pm 3.65$ & $19.00 \pm 1.76^{*}$ & $20.00 \pm 1.4^{*}$ & $25.00 \pm 1.7^{*}$ & $30.8 \pm 3.12$ \\
\hline & Treatment & $38.00 \pm 5.33$ & $16.00 \pm 1.87$ & $18.00 \pm 2.21$ & $21.00 \pm 1.76$ & $31.00 \pm 3.89$ \\
\hline \multirow{2}{*}{ Lactate (mmol/l) } & Control & $2.5 \pm 0.25$ & $6.00 \pm 0.93^{*}$ & $6.9 \pm 0.65^{*}$ & $5.8 \pm 0.28^{*}$ & $2.7 \pm 0.27^{*}$ \\
\hline & Treatment & $2.5 \pm 0.22$ & $2.7 \pm 0.3$ & $2.5 \pm 0.28$ & $2.0 \pm 0.37$ & $1.5 \pm 0.45$ \\
\hline
\end{tabular}

Hematological indices of cats in both groups. Using pulse oximetry during the surgical intervention in animals with acute blood loss made it possible to compare the $\mathrm{SpO} 2$ of the patients in the treatment and control groups on the 1 st day of admission. It is clearly seen that the $\mathrm{SpO} 2$ level of the animals in the treatment group after the administration of Perftoran, despite the severe blood loss, has not fallen below $95 \%$, which indicates the absence of hypoxemia. On the contrary, in the control group the $\mathrm{SpO} 2$ level dropped to $79 \%$, indicating a life-threatening hypoxemia.

During anesthesia saturation must always remain within $95-100 \%$. If the saturation is $94 \%$ or lower, the patient develops hypoxemia, and emergency measures must be carried out. Saturation below $90 \%$ requires urgent care $(6,17,18)$.

Our results have shown, that hematological parameters of the cats in the control group in all stages were almost identical to the parameters of the cats in the treatment group, however, the lactate level in the hydremic stage, i.e. 48 hours after the blood loss, increased above the reference values and tended to increase, which indicated the development of the tissue hypoxia of the injured animal, and only 7 days later after the injury the lactate level was reduced to reference values, which was associated with the increase in RBCs and decrease in tissue hypoxia. As a result of developing posthemorrhagic anemia of moderate severity, in injured animals their own endogenous compensation mechanisms activated, which allowed the body to replenish the lost volume of RBCs and maintain its viability.

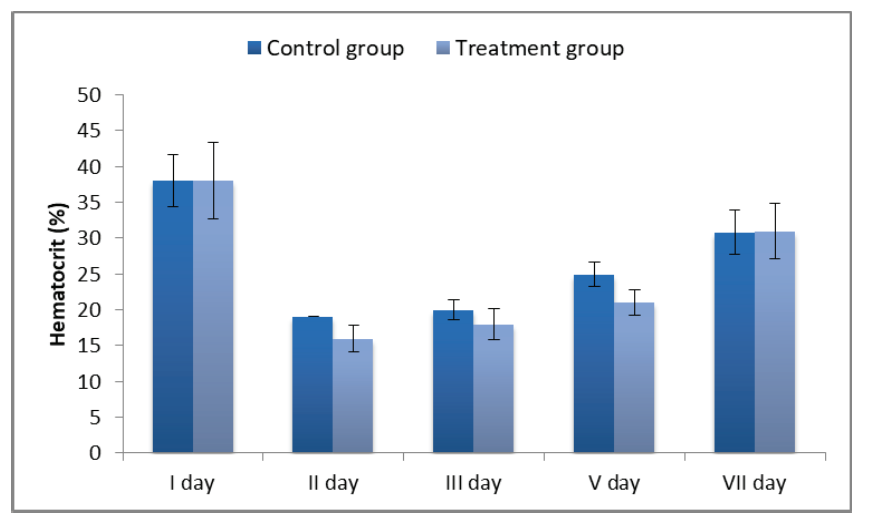

Figure 1. Hematocrit (\%) in control and experimental group during the experimental period. Values are presented as mean \pm standard deviations.
In the treatment group of animals, in comparison with the control group, the lactate level remained within the reference values for 7 days, despite the low level of RBCs, which indicated the absence of tissue hypoxia (Table 1, Figs. 1 and 2).

It is known that lactate in the animals is formed as a result of anaerobic metabolism. Its level increases due to the poor blood supply and tissue hypoxia. The range of normal lactate levels in cats is $0,5-2,8 \mathrm{mmol} / \mathrm{l}(5,18,19)$. Studies have shown that at injection of gas-carrying blood substitute Perftoran the lactate level has been significantly better in the treatment group. This is due to the gas-carrying properties of the perfluorocarbon emulsion - the basis of Perftoran (20).

The perfluorocarbon emulsion increases the mass transfer of $\mathrm{O}_{2}$ due to the following effects: an increase in level of physically dissolved $\mathrm{O}_{2}$ in the plasma (21); accelerated diffusion of $\mathrm{O}_{2}$ in perfluorocarbons; increase in saturation speed of $\mathrm{O}_{2}$ in perfluorocarbons; large surface area for gas exchange; intensification of $\mathrm{O}_{2}$ extraction by emulsion particles from the RBCs' hemoglobin; formation of a "pearl-thread" structure of perfluorocarbons in the bloodstream, which are oxygen channels, through which oxygen conductivity is $20-25$ times higher than in the plasma (21, 22).

Perfluorocarbon emulsion reduces the viscosity of the blood and improves the vascular bed, which facilitates the passage of RBCs through the capillaries, thus increases the delivery of $\mathrm{O}_{2}$; improves the parameters of gas composition and acid-base balance of blood, reduces acidosis.

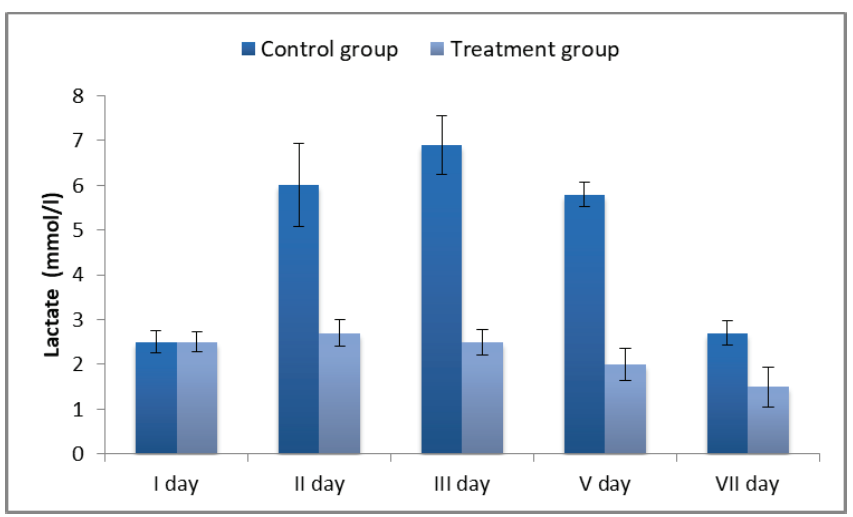

Figure 2. Lactate levels (mmol/l) in control and experimental group during the experimental period. Values are presented as mean \pm standard deviations. 


\section{CONCLUSIONS}

Based on the obtained results, the following conclusions can be drawn. The use of the gas-carrying substitute for donor blood Perftoran in the treatment group of animals with posthemorrhagic anemia, which resulted from polytrauma, eliminated tissue hypoxia. Also, the treatment of the animals in the control group with standard solutions (by infusing Stabisol) without gas transport correction led to the development of persistent hypoxia, which persisted to the stage of reticulocyte crisis. We can conclude that the use of Perftoran in correction of massive blood loss allows maintaining the level of gas transport properties of blood (SpO2) at the physiological level, which does not allow the hypoxemia to develop. Finally the use of Perftoran with strict adherence to the rules did not lead to adverse allergic reactions in animals. In the future, the clinical experience in treating animals with polytrauma allows the recommendation of perfluorocarbon based blood substitute with gas-carrying function Perftoran as an alternative substitute for donor blood.

\section{REFERENCES}

1. Alekseev NA. Anemia. SPb Hippocrates; 2004: 512.

2. Jones JA. Red blood cell substitutes: current status. $\mathrm{Br} J$ Anaesth. 1995;74(6):697-703.

3. Rentko VT. Red blood cell substitutes. Probl Vet Med. 1992;4(4):647-51.

4. Marchbank A. Fluorocarbon emulsions. Perfusion. 1995;10(2):67-88.

5. Michael D. Manual of Canine and Feline Haematology and Transfusion Medicine. Lookers, Upton, Poole, Dorset; 2000: 62-98.

6. Chandler EA, Gaskell CJ. Feline Medicine and Therapeutics. Aquarium; 2002; 696.

7. Rosen AL, Gould SA, Sehgal LR, Levine EA, Sehgal HL, Goldwasser E, Beaver CW, Moss GS. Erythropoietic response to acute anemia. Crit Care Med. 1990;18(3):298-302.

8. Authement JM, Wolfsheimer KJ, Catchings S. Canine blood component therapy: product preparation, storage, and administration. Journal of the American Animal Hospital Association; 1987: (23)483-493.

9. Bell K, Agar PG. Red Blood Cells of Domestic Mammals. Elsevier Science Publishers; 1983:163-164.

10. Clark-Price S. Practical uses of pulse oximeter and capnography. In: Proceedings of 15th IVECCS; 2009: 323-325.
11. Spiess BD. Military Supplement: Perfluorocarbon Emulsions, Platelet Counts and Inflammation. Shock. 2018; doi: 10.1097/SHK.0000000000001154.

12. Figueroa MS, Casas DR. Inflammation induced by perfluorocarbon liquid: intra- and postoperative use. Biomed Res Int. 2014; 2014:907816.

13. Ma M, Xu H, Chen H, Jia X, Zhang K, Wang Q, Zheng S, Wu R, Yao M, Cai X, Li F,Shi J. A drug-perfluorocarbon nanoemulsion with an ultrathin silica coating for the synergistic effect of chemotherapy and ablation by high-intensity focused ultrasound. Adv Mater. 2014; 26(43):7378-85.

14. Forgiarini LA Jr, Forgiarini LF, da Rosa DP, Mariano R, Ulbrich JM, Andrade CF. Endobronchial perfluorocarbon administration decreases lung injury in an experimental model of ischemia and reperfusion. J Surg Res. 2013; 183(2):835-40.

15. Cronin WA, Senese AL, Arnaud FG, Regis DP, Auker CR, Mahon RT. The effect of the perfluorocarbon emulsion Oxycyte on platelet count and function in the treatment of decompression sickness in a swine model. Blood Coagul Fibrinolysis. 2016; 27(6):702-10.

16. Randsøe T. Effect of metabolic gases and water vapor, perfluorocarbon emulsions, and nitric oxide on tissue bubbles during decompression sickness. Dan Med J. 2016;63(5).

17. Chang ET, Adami HO, Boffetta P, Wedner HJ, Mandel JS. A critical review of perfluorooctanoate and perfluorooctanesulfonate exposure and immunological health conditions in humans. Crit Rev Toxicol. 2016; 46(4):279-331.

18. Heilmann C, Jensen L, Weihe P, Nielsen F, Knudsen LE, Budtz-Jørgensen E, Mølbak K, Grandjean P. Persistant perfluorinated compounds cause immunotoxic effects. Ugeskr Laeger. 2014;176(9A):V09130572.

19. Cabrales P, Carlos Briceño J. Delaying blood transfusion in experimental acute anemia with a perfluorocarbon emulsion. Anesthesiology. 2011; 114(4):901-11.

20. Lundgren CE, Bergoe GW, Tyssebotn IM. Intravascular fluorocarbon-stabilized microbubbles protect against fatal anemia in rats. Artif Cells Blood Substit Immobil Biotechnol. 2006; 34(5):473-86.

21. Habler O, Kleen M, Hutter J, Podtschaske A, Tiede M, Kemming G, Welte M, Corso C, Batra S, Keipert P, Faithfull S, Messmer K. IV perflubron emulsion versus autologous transfusion in severe normovolemic anemia: effects on left ventricular perfusion and function. Res Exp Med (Berl). 1998;197(6):301-18.

22. Habler OP, Kleen MS, Hutter JW, Podtschaske AH, Tiede M, Kemming GI, Welte MV, Corso CO, Batra S, Keipert PE, Faithfull NS, Messmer KF. Effects of hyperoxic ventilation on hemodilution-induced changes in anesthetized dogs. Transfusion. 1998;38(2):135-44. 